\title{
7. SOUTHEAST PACIFIC OCEAN TRANSECT, TAHITI TO PANAMA: GEOPHYSICAL PROFILES FROM DEEP SEA DRILLING PROJECT LEG 921
}

\author{
David K. Rea, Department of Atmospheric and Oceanic Science, The University of Michigan ${ }^{2}$
}

\begin{abstract}
The Glomar Challenger left Tahiti in February of 1983, sailed $4621 \mathrm{mi}$. during Leg 92, and anchored in Panama 2 mo. later. During the cruise, geophysical profiles were acquired across the Society and Tuamotu seamount chains, the East Pacific Rise, the Bauer Basin, the Carnegie Platform and Ridge, and the Panama Basin.
\end{abstract}

\section{INTRODUCTION}

Leg 92 of the Deep Sea Drilling Project traversed $4621 \mathrm{mi} .(8558 \mathrm{~km})$ across the southeastern Pacific Ocean, from Papeete, Tahiti, to Balboa, Panama (Fig. 1). The Glomar Challenger departed Papeete on 23 February 1983 and arrived in Balboa on 18 April.

We collected $12 \mathrm{kHz}, 3.5 \mathrm{kHz}$, and air or water gun continuous seismic reflection profiles and total field magnetometer measurements along the track line. On board the Challenger, total field magnetic data and depths from echo sounders (which were calibrated by assuming a 1500 $\mathrm{m} / \mathrm{s}$ sound velocity) were recorded every $5 \mathrm{~min}$. These data were keypunched on shore, plotted in profile form, and edited by DSDP by being compared with the original analog records.

Satellite fixes and all course and speed changes were recorded on board, keypunched on shore, and checked by being run through a navigation smoothing computer program. Results were edited on the basis of reasonable speeds and courses as determined by the program. The corrected navigational data were then merged with the geophysical information to plot the various profiles. Track lines with hourly ticks and day designators appear in Figure 2. Bathymetry and magnetic anomaly profiles, which were determined by removing the 1980 international geomagnetic reference field (IGRF), are plotted in Figure 3. Annotations on these profiles include nautical miles along track, days, course changes greater than $30^{\circ}$, drill sites, major topographic or structural features, and magnetic anomaly identifications. Figure 4 (in back pocket) shows the seismic reflection profiles recorded on the Edo-1 recorder at a $5 \mathrm{~s}$ sweep rate. Vertical exaggeration, at a ship speed of 9 knots, is $\times 24$. All navigation and geophysical data are on file at the Geologic Data Center, Scripps Institution of Oceanography.

\section{GEOPHYSICAL NARRATIVE}

\section{Society and Tuamotu Seamount Chains}

The underway geophysical records for Leg 92 begin a few miles south of the island of Tahiti. The first geologic feature crossed is the Society seamount chain (Fig.

\footnotetext{
${ }^{1}$ Leinen, M., Rea, D. K., et al., Init. Repts. DSDP, 92: Washington (U.S. Govt. Printing Office).

2 Address: Oceanography Program, Department of Atmospheric and Oceanic Science, The University of Michigan, Ann Arbor, MI 48109.
}

$3 \mathrm{~A}$, miles 0 to 140 ). We crossed the broad Tuamotu chain obliquely (Figs. 3A and 3B, miles 300 to 970). Between the narrow ridge at mile 320 and the ensuing one at mile 445 , there is up to $0.25 \mathrm{~s}$ of horizontally layered sediment, which is highly reflecting in the upper portion and becomes more transparent with increasing depth. A normal fault with about $0.25 \mathrm{~s}$ of basement offset has tilted some of the sedimentary layers (Fig. 3A, mile 400; Fig. 4). The flat-lying sediments are presumed to be turbidites shed from the Tuamotu seamount chain.

The main ridge of the Tuamotus between miles 630 and 970 exhibits sediment accumulations on the more gentle slopes and in ponds between the peaks. Sediments on the ridge are generally transparent, with few internal reflectors; those in the ponds show parallel reflectors and, rarely, evidence of angular discordance (Fig. 4).

Magnetic anomalies along this part of the profile range up to $500 \mathrm{nT}$ in amplitude but are not readily correlatable to the known Tertiary spreading-anomaly sequence.

\section{East Pacific Rise}

All of the Leg 92 drill sites are on the west flank of the East Pacific Rise (EPR) (Fig. 1). The rise exhibits the typical topography of fast-spreading centers: low abyssal hills, commonly 50 to $100 \mathrm{~m}$ high (Figs. 3B to 3E, miles 970 to 2770; Fig. 4). Up to $0.10 \mathrm{~s}$ of pelagic sediment drapes over the low hills; it shows little evidence of ponding or other reworking.

Portions of the EPR west flank were generated by the fossil spreading centers now in the center of the Nazca Plate (Herron, 1972; Mammerickx et al., 1975; Handschumacher, 1976; Rea, 1978a; Mammerickx et al., 1980). Along the Leg 92 track line at $19^{\circ} \mathrm{S}$, the Austral Fracture Zone (Fig. 3C, mile 1390) divides lithosphere formed at the fossil Mendoza Rise to the west and north from lithosphere formed at the modern EPR to the east and south. Site 597 lies on Mendoza Rise crust, the others on EPR crust.

The axial ridge of the EPR, which we crossed at about $113.0^{\circ} \mathrm{W}, 16.6^{\circ} \mathrm{S}$ (Fig. 3D, mile 2165), is about $350 \mathrm{~m}$ high and reaches a minimum depth of $2655 \mathrm{~m}$ (uncorrected). Halfway down the east flank of the rise, the Challenger crossed the Garrett Fracture Zone (Fig. 3E, mile 2470). This feature may separate the symmetrically spreading portion of the EPR axis north of $13^{\circ} \mathrm{S}$ from the asymmetrically spreading portion to the south (Rea, 1981). 


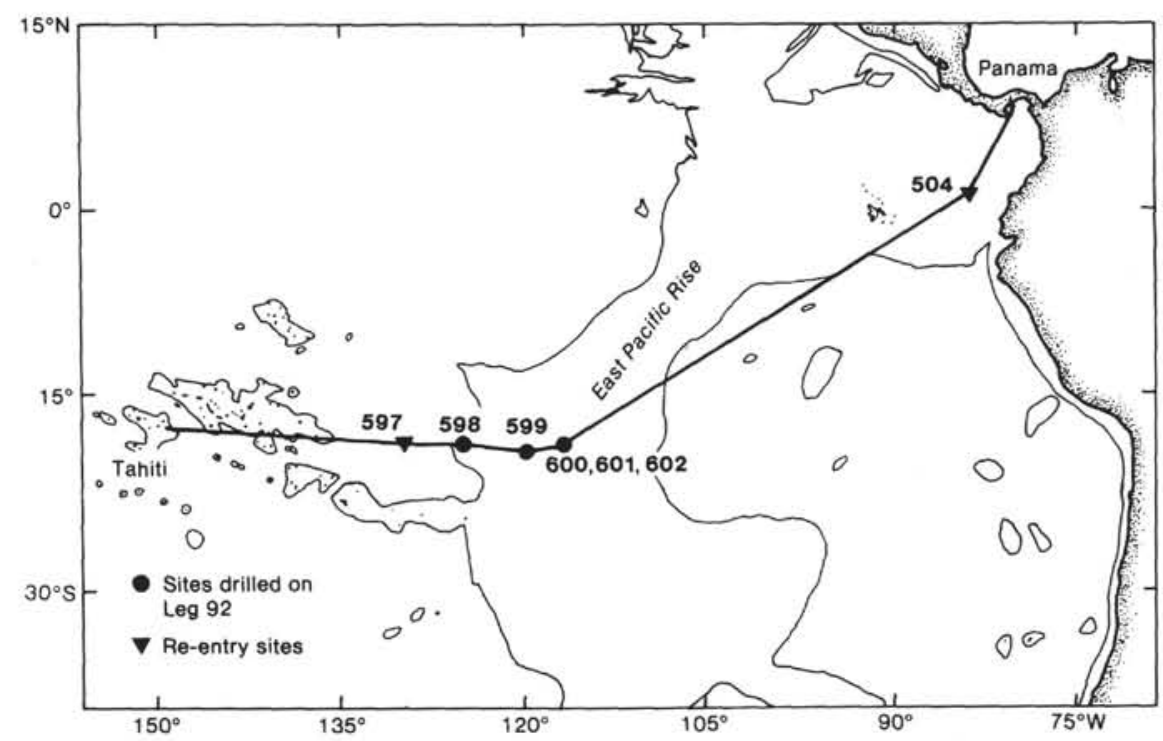

Figure 1. DSDP Leg 92 site locations and approximate track line. Inverted triangle denotes re-entry.

North of the Garrett Fracture Zone, the eastern boundary of the modern EPR lies along the Bauer Scarp, which separates EPR crust from crust formed at the fossil Galapagos Rise to the east. The Bauer Scarp is one result of the series of ridge jumps that created the present EPR north of $13^{\circ} \mathrm{S}$ between 8.2 and 5.7 Ma (Rea, 1976, 1978a).

Seafloor spreading magnetic anomalies can be identified along the EPR portion of the track line and correlated to the detailed annotation schemes of Ness et al. (1980) and Harland et al. (1982); Figures 3B to 3D show the general anomaly identifications. Spreading rates were calculated by two slightly different methods. First, rates were determined so that each site, when possible, was in the middle of the anomaly-bound interval. These values then represent the rate of crustal formation at each locality. The anomalies chosen to bracket the intervals are given in Table 1; rates were determined along the flowline direction of $103^{\circ}$ as determined from fracture zone trends.

Another calculation was made to determine the average spreading rates for the seafloor between the drill sites, values that are useful for determining past distances to the axis. For these calculations, the magnetic anomaly basement age of each site and distance between sites were used; again rates were determined parallel to the spreading direction of $103^{\circ}$ (Table 1).

Sites 597 and 598 lie on crust generated at a rate of 55 to $58 \mathrm{~km} / \mathrm{m}$.y., Site 599 on crust generated at $73 \mathrm{~km} /$ m.y., and Sites 600 to 602 on crust generated at $84 \mathrm{~km} /$ m.y. The present west flank spreading rate is $70.4 \mathrm{~km} /$ m.y. in the $20^{\circ} \mathrm{S}$ EPR axial survey area (Rea, 1978b) and $66.5 \mathrm{~km} / \mathrm{m}$.y. along the Leg 92 track, which crosses the axis at $16.6^{\circ} \mathrm{S}$ (Table 1). The new information to be derived from the values in the table is the high spreading rate of $93 \mathrm{~km} / \mathrm{m}$.y. for the interval between Sites 599 and 600-602.

\section{Bauer Basin}

The Bauer Basin, which lies between the EPR and the fossil Galapagos Rise, occurs between miles 2770 and
3700 along the Leg 92 track line (Figs. $3 \mathrm{E}$ to $3 \mathrm{G}$ ). The position of the northern edge of the Bauer Basin and the southern edge of the Carnegie Platform (Fig. 3G) was chosen arbitrarily.

The topography of the Bauer Basin is more rugged than it is along the EPR, with several hundred meters of relief south of Gofar Fracture Zone and perhaps $200 \mathrm{~m}$ of relief to the north. Increased sediment accumulation north of about $5^{\circ} \mathrm{S}$ reduces the topographic relief.

Seismic-reflection profiles (Fig. 4) show 0.1 to $0.2 \mathrm{~s}$ of sediment in the central portion of the Bauer Basin. Farther north, the influence of the equatorial high-productivity zone becomes important, and sediment thickness approaches or exceeds $0.5 \mathrm{~s}$. The sediments display multiple internal reflectors that appear to conform to basement. Numerous vertical offsets occur; many penetrate the entire sediment column.

The southeastern extension of the broad Gofar Fracture Zone occurs between miles 3110 and 3200 (Fig. 3F). This fracture zone is probably the direct geological descendant of the transform fault that, prior to about 12 $\mathrm{Ma}$, must have linked the northern end of the fossil Galapagos Rise with the southern end of the now extinct Mathematicians-Clipperton spreading ridge, which presently lies at $3^{\circ} \mathrm{S}, 115^{\circ} \mathrm{W}$ (Rea and Malfait, 1974; van Andel et al., 1975; Rea, 1978a). Along the Leg 92 track line, crust south of the Gofar Fracture Zone was formed at the Galapagos Rise, that to the north at the EPR.

Seafloor spreading magnetic anomalies are not identifiable in the Bauer Basin. Two distinct anomalies, at miles 3130 and 3180 (Fig. 3F), occur in conjunction with the Gofar Fracture Zone.

\section{Carnegie Platform and Ridge}

The Carnegie Platform and Ridge (Fig. 3G, miles 3700 to 4050) lie on seafloor formed along the Galapagos Rift zone (GRZ) in the Panama Basin. The transition to GRZ crust is apparent in both the bathymetry (the shoaling at about mile 3700) and the magnetic anomalies (which show a sudden increase in amplitude at mile 3750). This tran- 


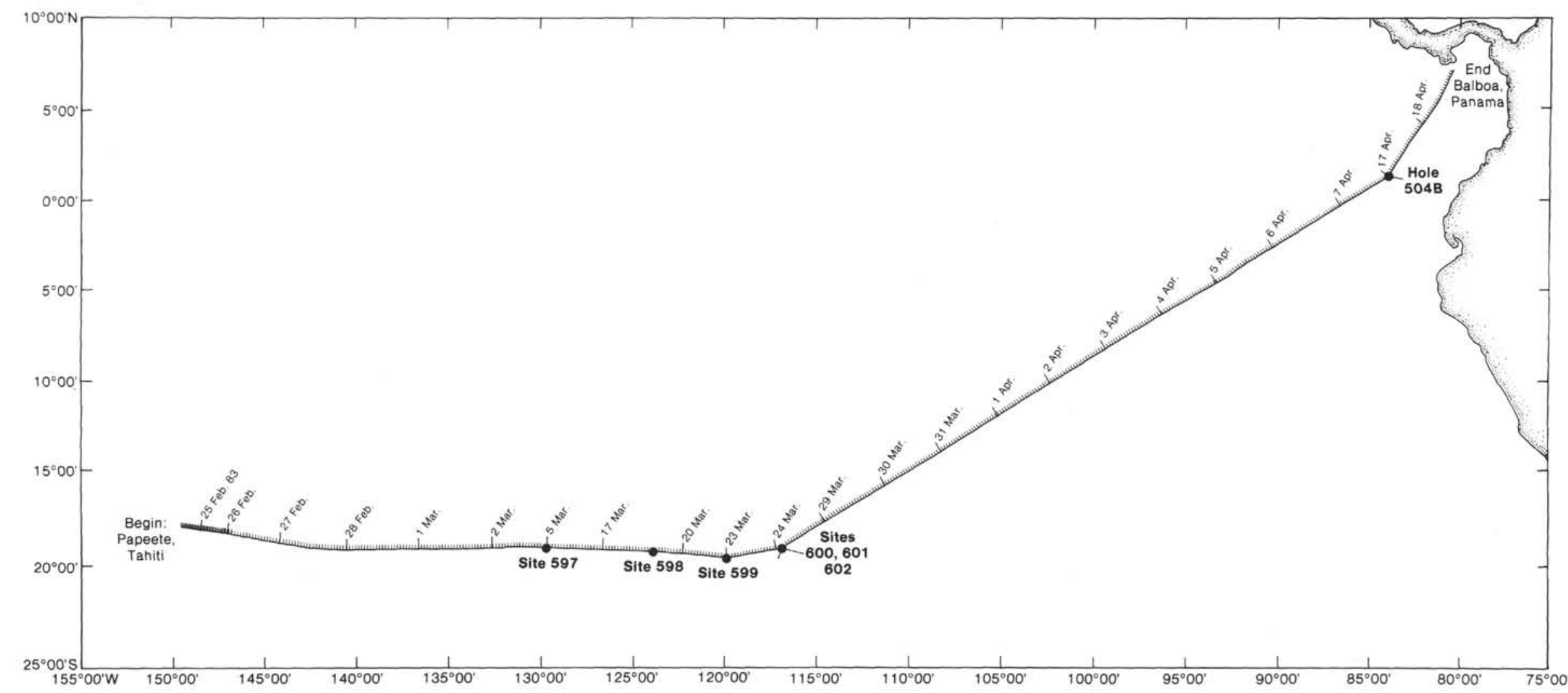

Figure 2. Map of Leg 92 track line showing day designators and hourly tick marks. Slow progress from 24 to 26 February was the result of typhoon Nisha. 
Table 1. Seafloor spreading rates along the Leg 92 trackline. Anomaly nomenclature and time scale are from Harland et al. (1982).

\begin{tabular}{|c|c|c|c|c|}
\hline Site & $\begin{array}{c}\text { Spreading } \\
\text { rate for interval } \\
\text { with site in center } \\
(\mathrm{km} / \mathrm{m} . \mathrm{y} .)\end{array}$ & $\begin{array}{c}\text { Anomalies } \\
\text { bounding intervals }\end{array}$ & $\begin{array}{l}\text { Anomaly age } \\
\text { of basement } \\
\text { at site } \\
\text { (Ma) }\end{array}$ & $\begin{array}{c}\text { Spreading } \\
\text { rate between } \\
\text { drill sites } \\
(\mathrm{km} / \mathrm{m} . \mathrm{y} .)\end{array}$ \\
\hline 597 & 55.4 & $\begin{array}{l}\text { Young edge } 12 \text {, } \\
\text { young edge } 7\end{array}$ & 28.6 & \\
\hline 598 & $57.8^{\mathrm{b}}$ & $\begin{array}{l}\text { Old edge 5B.1, } \\
\text { young edge 5A.1 }\end{array}$ & 16.0 & (1) \\
\hline 599 & 73.3 & $\begin{array}{c}\text { Young edge 5A.1, } \\
\text { old edge } 3 \mathrm{~A}\end{array}$ & 7.8 & 61.2 \\
\hline $600-602$ & 84.0 & Old edge $3 \mathrm{~A}$, & 4.6 & 93.1 \\
\hline Axis & $c_{70.4} /{ }^{d} 66.5$ & $\begin{array}{l}\text { Young edge } 2 \mathrm{~A} \text {, } \\
\text { axis }\end{array}$ & 0 & 75.6 \\
\hline
\end{tabular}

a Discontinuity at Austral Fracture Zone (see text).

From anomalies younger than site only.

In the $20^{\circ} \mathrm{S}$ survey area (Rea, 1978b).

Along the Leg 92 axis crossing at $16.6^{\circ} \mathrm{S}$.

sition in the magnetic pattern from smooth to rough is especially indicative of a traverse from crust formed near the equator at a north-south-trending axis to crust formed at an east-west-trending spreading axis (Hey, 1977; Hey et al., 1977).

The seafloor of the Galapagos Platform exhibits low relief $(50$ to $100 \mathrm{~m})$. A sedimentary sequence 0.3 to $0.5 \mathrm{~s}$ thick and characterized by numerous parallel reflectors overlies the platform. Small vertical offsets are common to abundant (Fig. 4). The sedimentary section thins out against the Carnegie Ridge so that accumulation is minimal above depths of about $2.25 \mathrm{~s}(1700 \mathrm{~m})$ on the south flank and $3.0 \mathrm{~s} \mathrm{(2250)}$ on the north side.

The ridge itself (Fig. 3G, mile 3940) reaches a least depth of $1.13 \mathrm{~s}$ ( $848 \mathrm{~m}$, uncorrected). Lower on its flanks, faulting and erosion have affected the sedimentary section, and the sediments display internal angular discordances (Fig. 4).

Magnetic anomalies in the region of the Carnegie Platform and Ridge have been correlated by Hey (1977) and by Lonsdale and Klitgord (1978) to the series of reversals associated with Anomalies 5 and 6. The work of those authors is in only approximate agreement, however, so the anomaly identifications and, therefore, the geologic history of this region are not yet fully resolved.

\section{Panama Basin}

The Panama Basin is characterized by rugged bathymetry and high-amplitude magnetic anomalies (Figs. 3G and $3 \mathrm{H}$, miles 4050 to 4621 ). Relief along the Panama Fracture Zone (miles 4310 to 4340 ) and adjacent Malpelo Ridge (miles 4340 to 4430 ) exceeds $2000 \mathrm{~m}$. The seafloor in the southeastern Panama Basin was generated along short transform-fault-bound segments of the Galapagos Rift (Hey, 1977; Lonsdale and Klitgord, 1978); the Challenger track line never crossed the rift axis. The tectonics of this region are complex. Anomaly identification along parts of the region traversed by the Challenger have been made by Hey (1977) and Lonsdale and Klitgord (1978).
Sediment cover in the Panama Basin (Fig. 4) is thin and irregular on the steeper slopes but moderately thick in the more level positions. Ponding appears to be common. There is $0.3 \mathrm{~s}$ of sediment in the vicinity of Site 504 that does not show coherent internal reflectors, possibly because of the many small vertical offsets. The seaward wall of the Colombian-Panama Trench has 0.4 to $0.6 \mathrm{~s}$ of generally transparent sediment. Within the trench itself the sediment thickness could not be determined; the Edo-1 recorder was able to follow basement to a subbottom depth of $0.9 \mathrm{~s}$ before losing it. The trench sediments are characterized by a few faint, flat-lying reflectors (Fig. 4).

\section{ACKNOWLEDGMENTS}

On board the Challenger, T. Gustafson, the laboratory officer, ensured a smooth data-handling operation. The plots and profiles presented here were generated by the Geological Data Center at the Scripps Institution of Oceanography. I thank Keir Becker for providing a review of the manuscript.

\section{REFERENCES}

Handschumacher, D. W., 1976. Post-Eocene plate tectonics in the eastern Pacific. In Sutton, G. H., Manghnani, M. H., Moberly, R. (Eds.), The Geophysics of the Pacific Ocean Basin and its Margin. Am. Geophys. Union Monogr., 19:177-202.

Harland, W. B., Cox, A. V., Llewellyn, P. G., Pickton, C. A. G., Smith, A. G., and Walters, R., 1982. A Geologic Time Scale: Cambridge (Cambridge Univ. Press).

Herron, E. M., 1972. Sea floor spreading and the Cenozoic history of the east-central Pacific. Geol. Soc. Am. Bull., 83:1671-1692.

Hey, R., 1977. Tectonic evolution of the Cocos-Nazca spreading center. Geol. Soc. Am. Bull., 88:1404-1420.

Hey, R., Johnson, G. L., and Lowrie, A., 1977. Recent plate motions in the Galapagos area. Geol. Soc. Am. Bull., 88:1385-1403.

Lonsdale, P., and Klitgord, K. D., 1978. Structure and tectonic history of the eastern Panama Basin. Geol. Soc. Am. Bull., 89:981-999.

Mammerickx, J., Anderson, R. N., Menard, H. W., and Smith, S. M., 1975. Morphology and tectonic evolution of the east-central Pacific. Geol. Soc. Am. Bull., 86:111-118.

Mammerickx, J., Herron, E., and Dorman, L., 1980. Evidence for two fossil spreading ridges in the southeast Pacific. Geol. Soc. Am. Bull., 91(pt. I):263-271.

Ness, G., Levi, S., and Couch, R., 1980. Marine magnetic anomaly timescales for the Cenozoic and Late Cretaceous: a precis, critique, and synthesis. Rev. Geophys. Space Phys., 18:753-770.

Rea, D. K., 1976. Analysis of a fast-spreading rise crest: the East Pacific Rise, $9^{\circ}$ to $12^{\circ}$ South. Mar. Geophys. Res., 2:291-313. 1978a. Evolution of the East Pacific Rise between $3^{\circ} \mathrm{S}$ and $13^{\circ} \mathrm{S}$ since the middle Miocene. Geophys. Res. Lett., 5:561-564. 1978b. Asymmetric sea floor spreading and a nontransform axis offset: the East Pacific Rise $20^{\circ} \mathrm{S}$ survey area. Geol. Soc. Am. Bull., 89:836-844.

1981. Tectonics of the Nazca-Pacific divergent plate boundary. In Kulm, L. D., Dymond, J., Dasch, E. J., and Hussong, D. M. (Eds.), Nazca Plate: Crustal Formation and Andean Convergence. Mem. Geol. Soc. Am., 154:27-62.

Rea, D. K., and Malfait, B. T., 1974. Geologic evolution of the northern Nazca Plate. Geology, 2:317-320.

van Andel, T. H., Heath, G. R., and Moore, T. C., 1975. Cenozoic History and Paleoceanography of the Central Equatorial Pacific Ocean. Mem. Geol. Soc. Am. 143.

Date of Initial Receipt: 3 July 1984

Date of Acceptance: 26 December 1984 

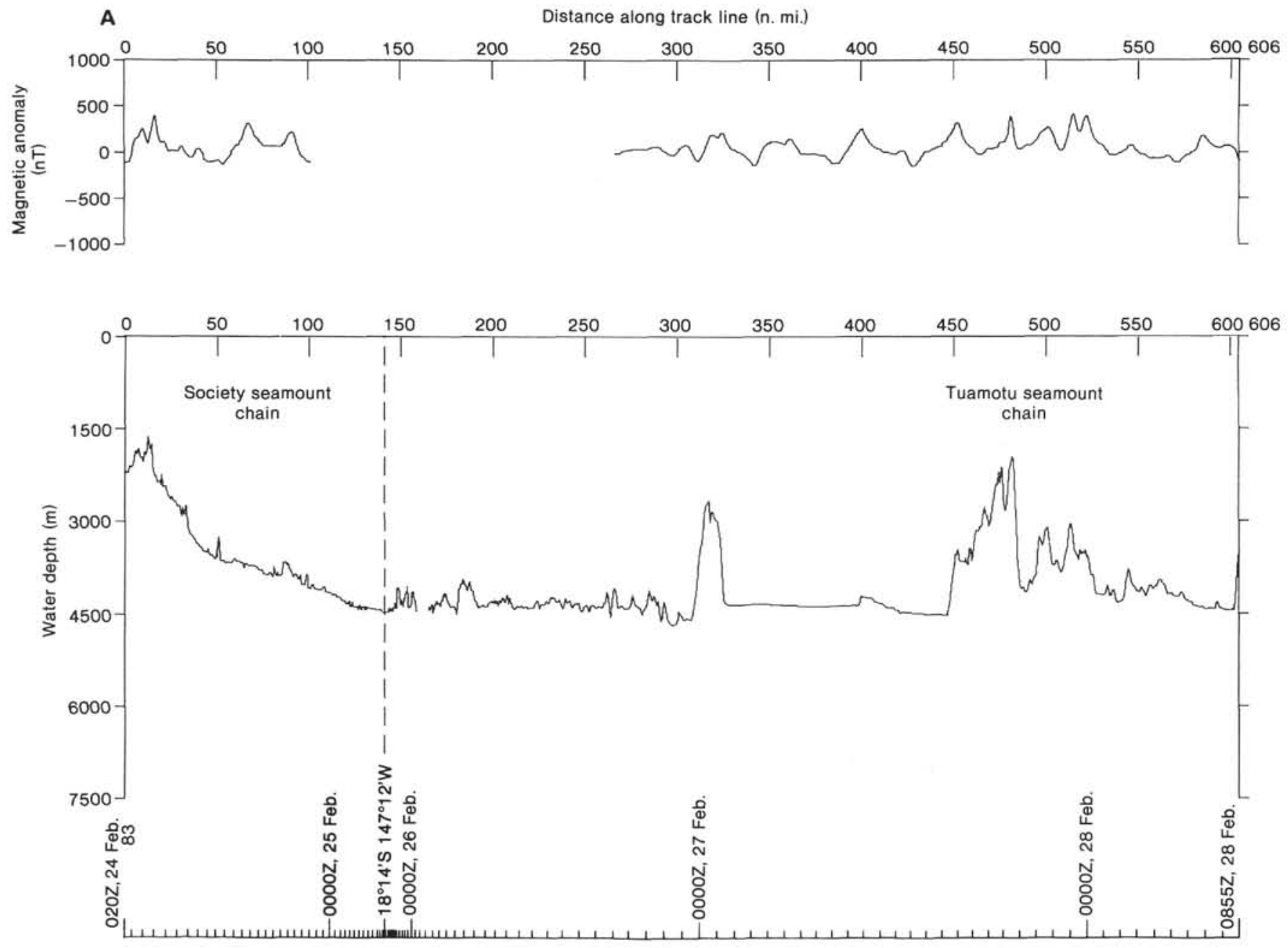

Figure 3. Bathymetric and magnetic anomaly profiles along the track line of Leg 92 . The bottom line shows hourly tick marks, days, locations of drill sites, and some larger course changes. Numbers along tops of profiles are distance along track line in nautical miles. Geological provinces, major structural features, magnetic anomalies, and DSDP sites are labeled. A to $\mathrm{H}$ are track line segments referred to in text. 
D. K. REA
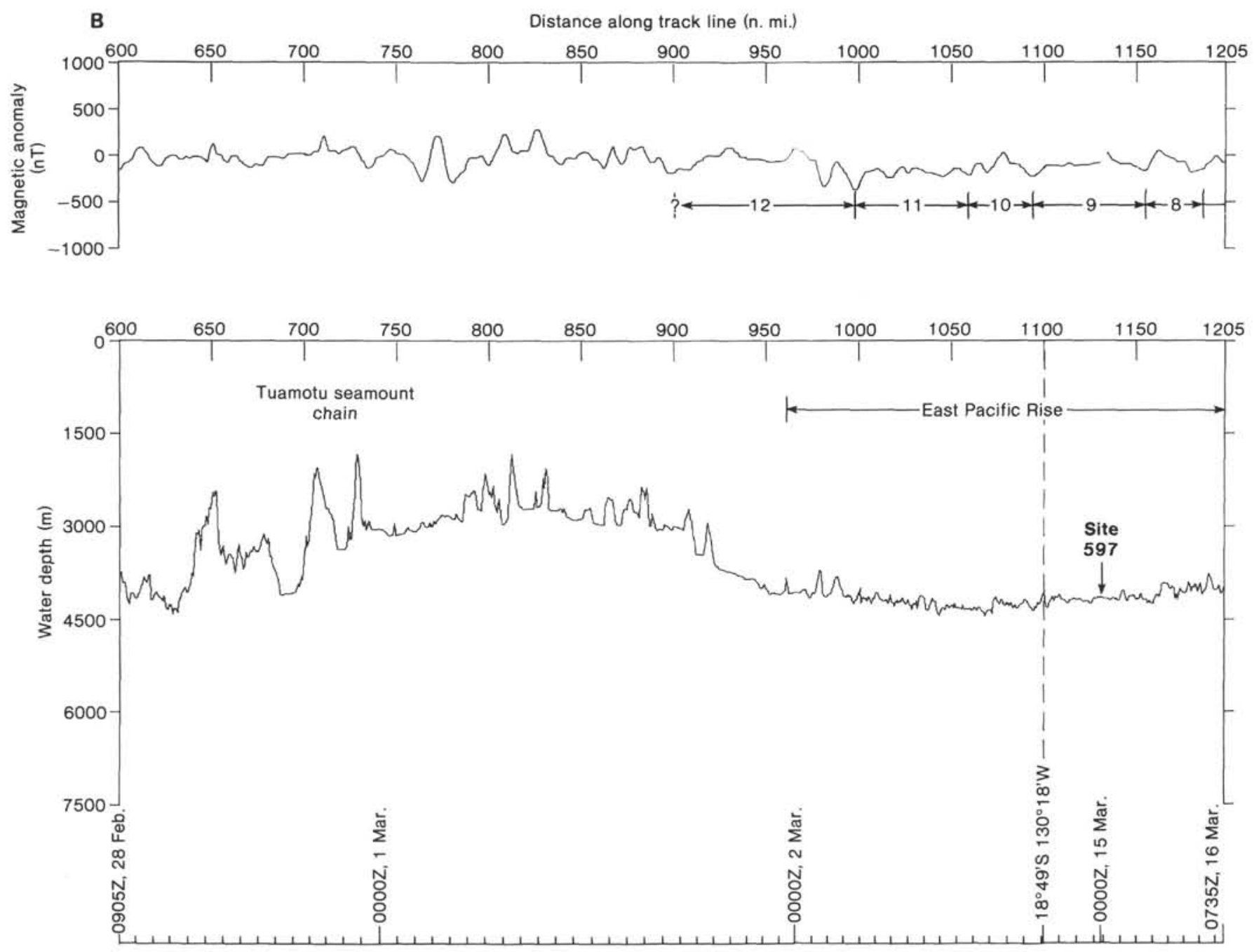

Figure 3 (continued). 

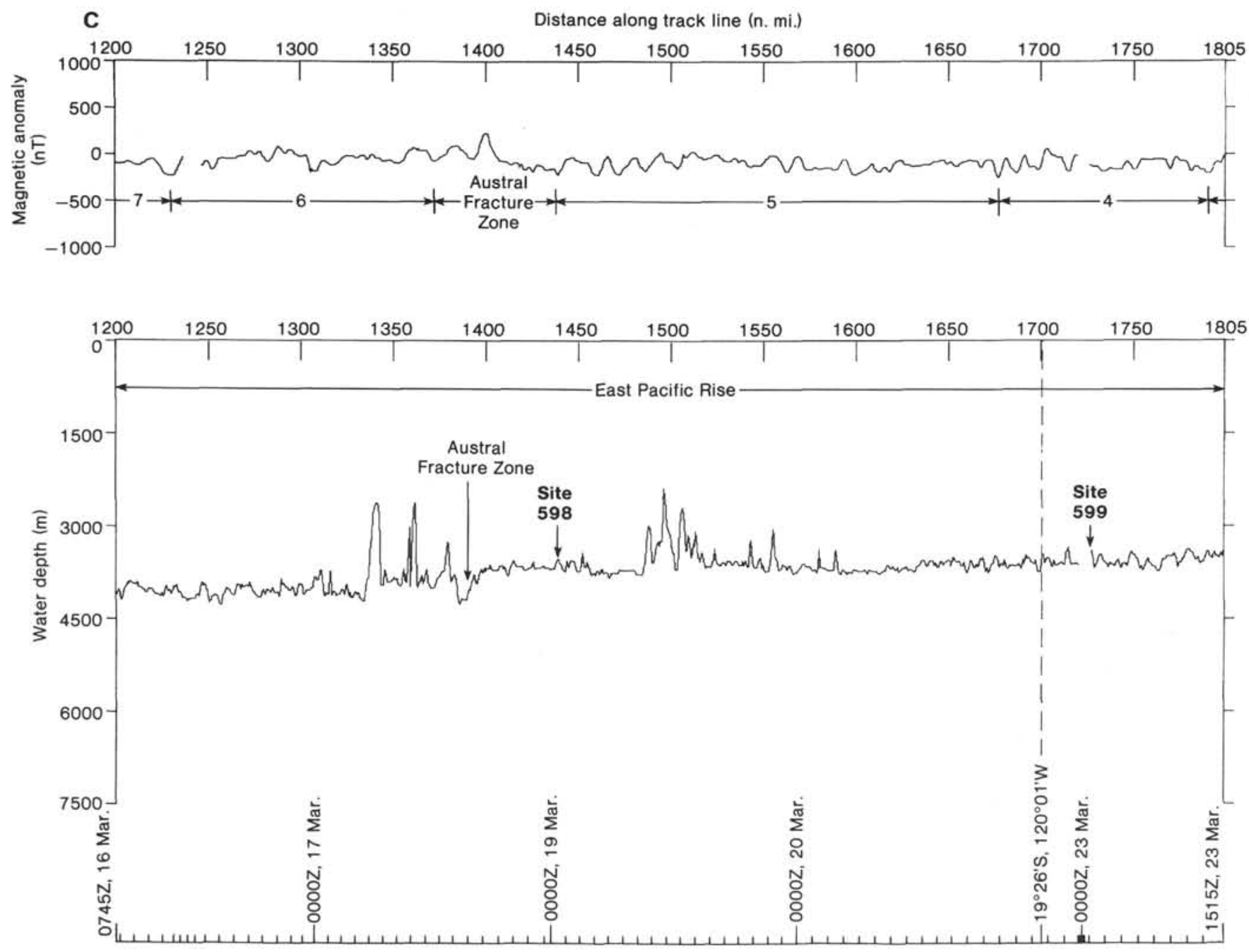

Figure 3 (continued). 

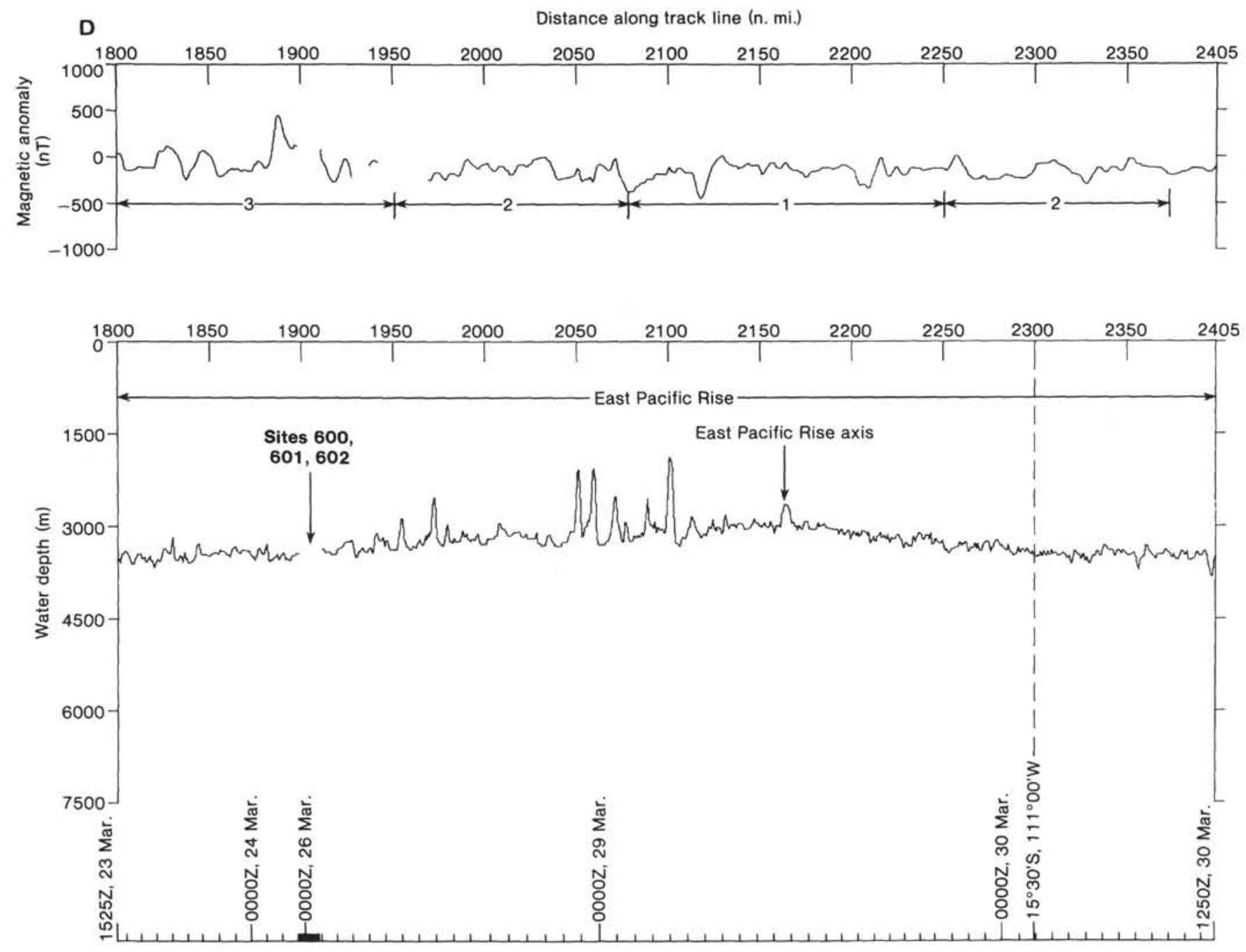

Figure 3 (continued). 

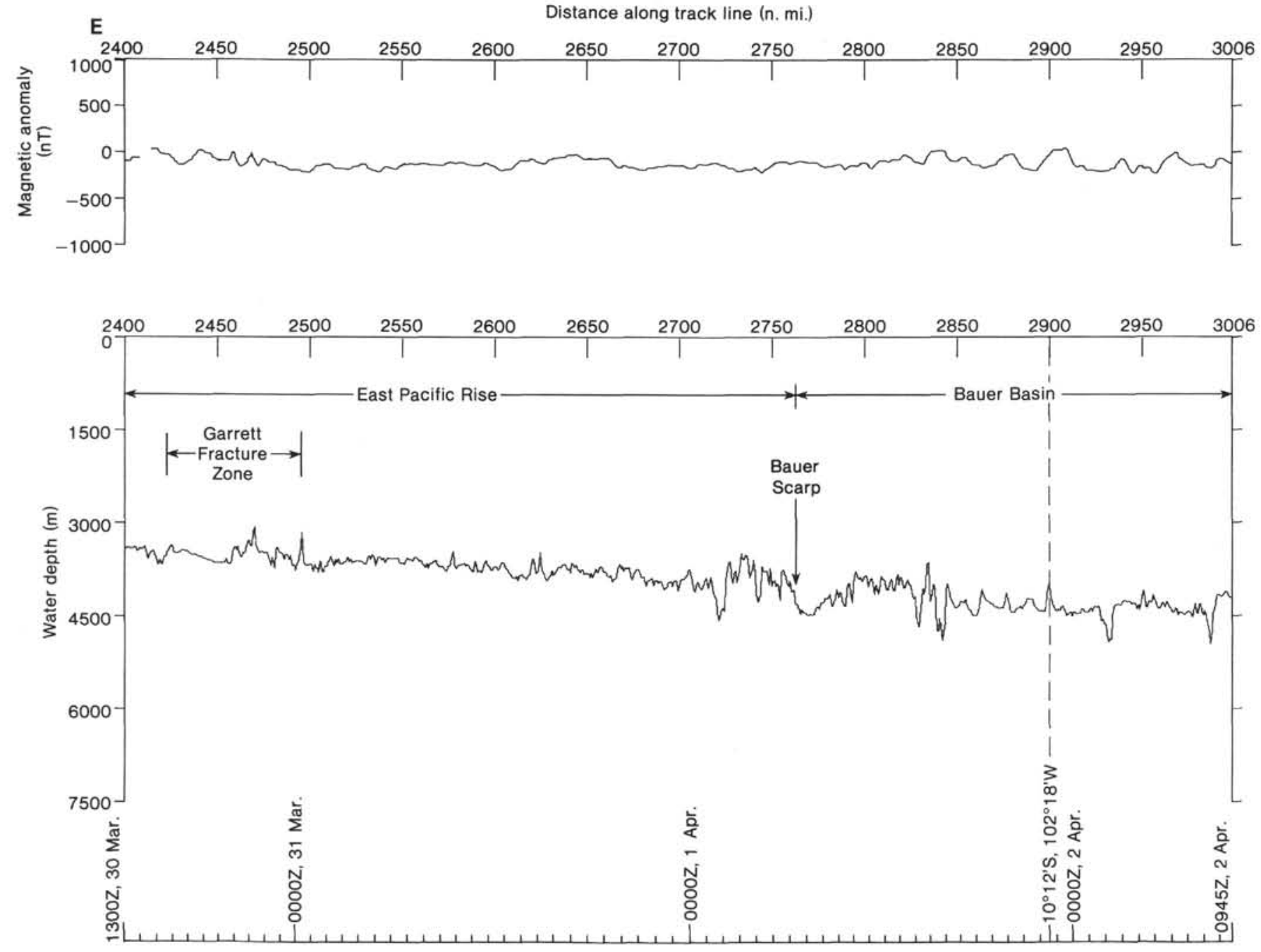

Figure 3 (continued). 
D. K. REA
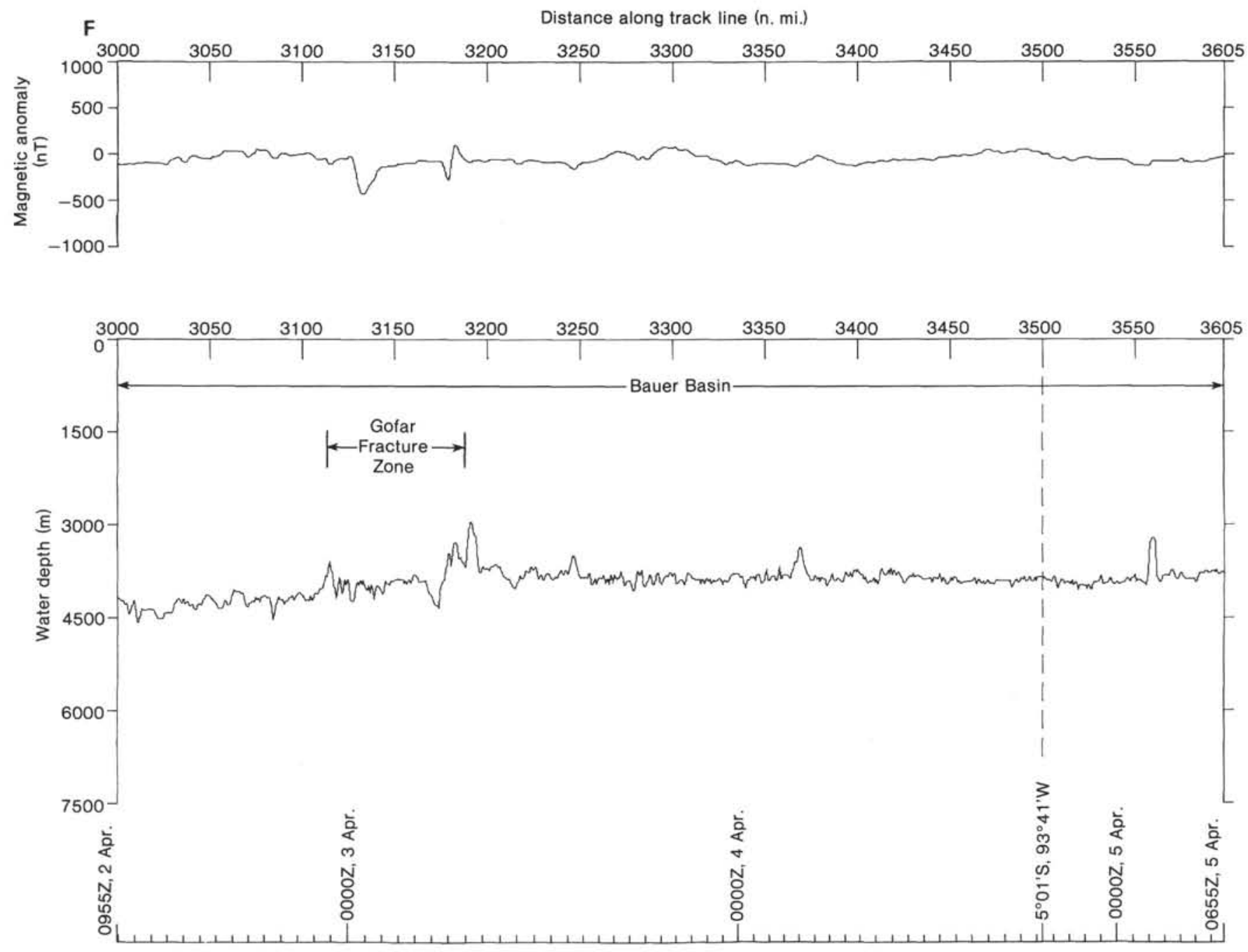

Figure 3 (continued). 

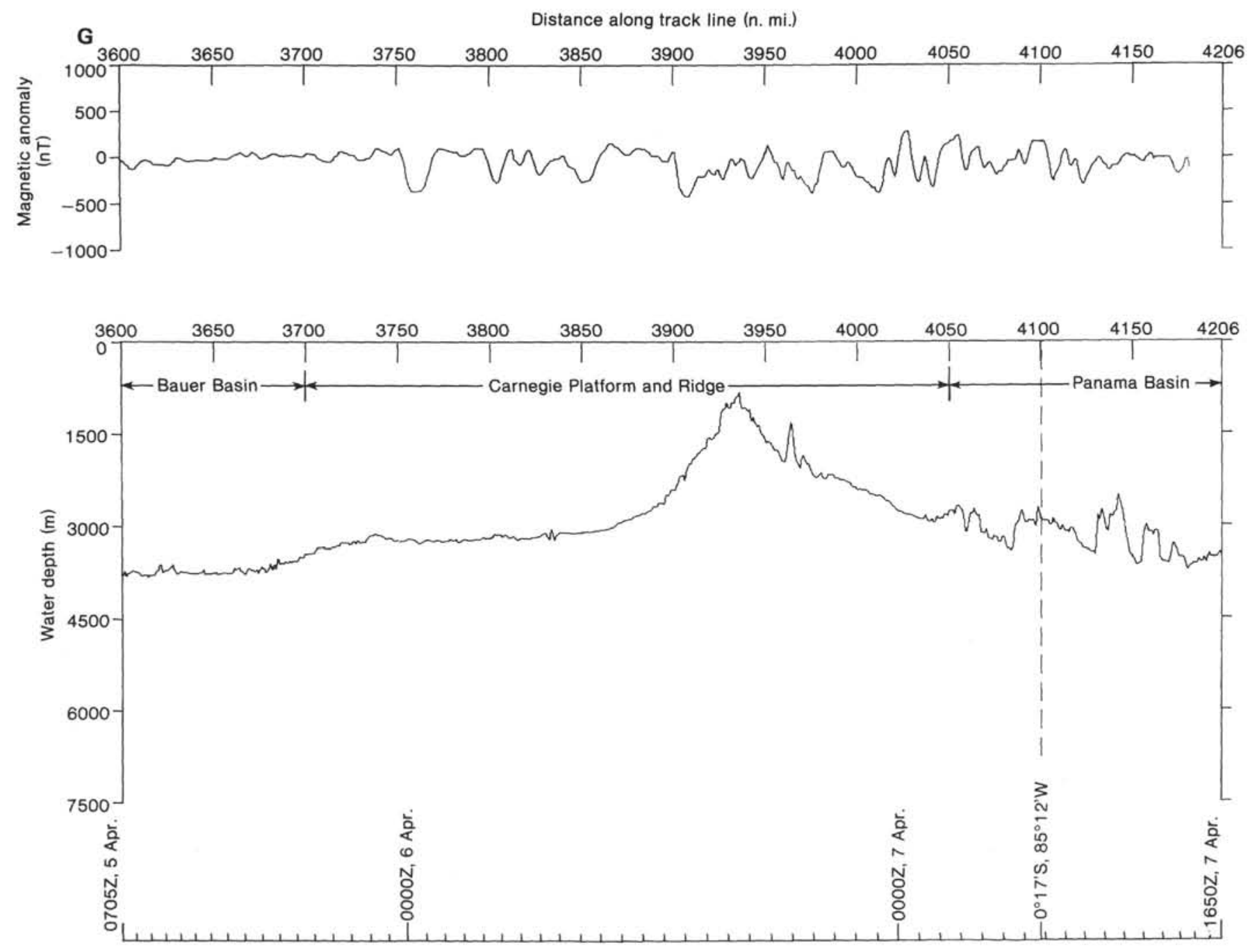

Figure 3 (continued). 

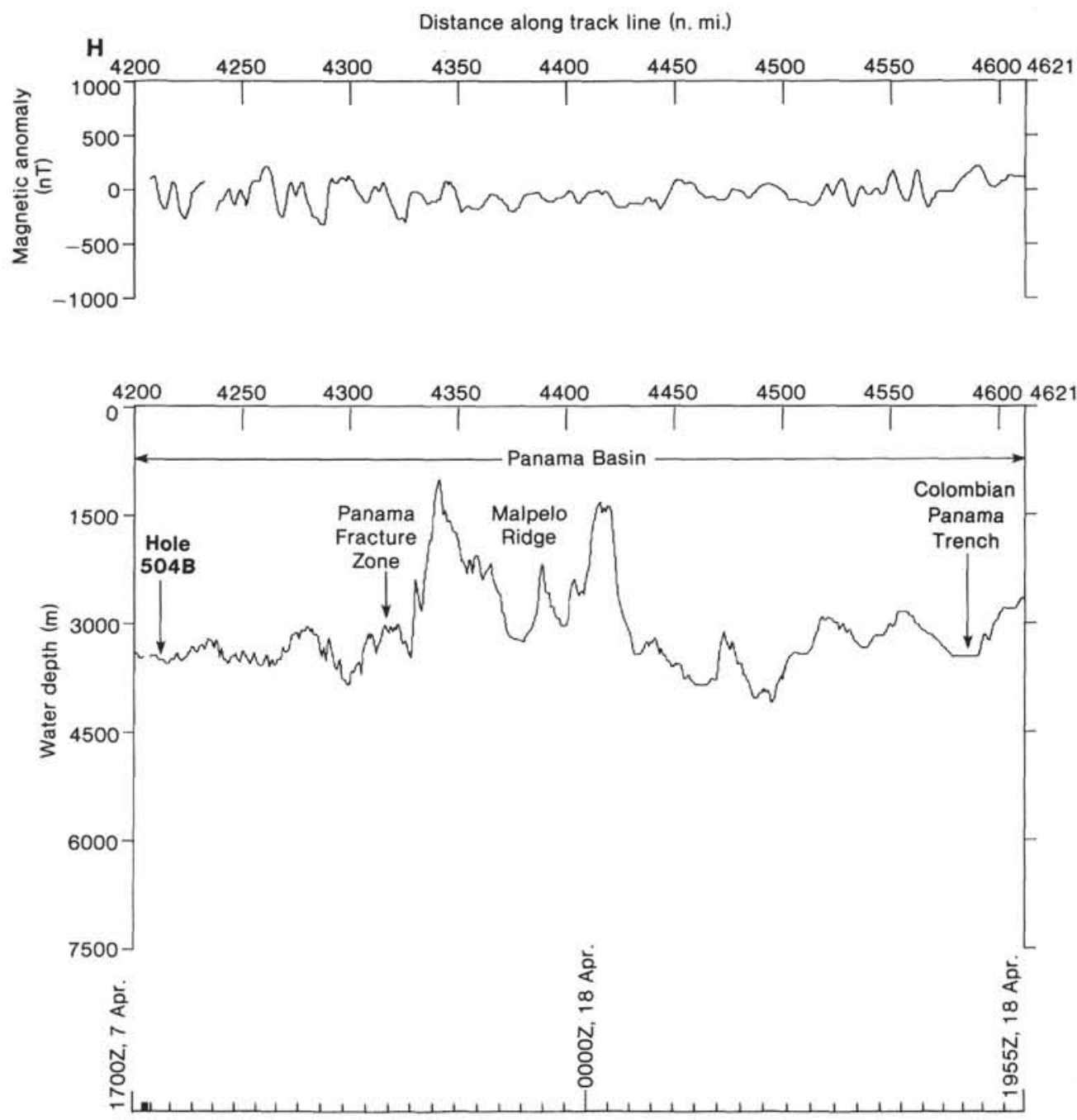

Figure 3 (continued). 